\title{
Research Paper Economic analysis of export performance of major Indian spices
}

\section{- Venkata Prasad Babu Anantha and Baljinder Kaur Sidana}

See end of the paper for authors' affiliations

Correspondence to :

Venkata Prasad Babu

Anantha

Department of Economics and Sociology, College of Basic Sciences and

Humanities, Punjab Agricultural University, Ludhiana (Punjab) India

Email : avprasadbabu4848 @gmail.com

Paper History :

Received : 09.07.2019;

Revised : 25.07.2019;

Accepted : 26.08.2019
ABSTRACT : India is often referred as the "spice hub of the world" because of its larger production and export potentiality of spices in the world. The present study examines the direction of trade of major spices export from India to different destinations during 1995-96 to 2016-17. The study utilizes Markov chain analysis and calculate the transitional probability matrices for all major spices to determine the direction of spices export from India. The total study period has been divided into two periods based on National Horticulture Mission viz., pre-NHM (1995-96 to 2005-06) and post-NHM (2006-07 to 2016-17). The study revealed that the retention capacity of export destinations for Indian chilli increased after National Horticulture Mission. However, many major importers have registered lesser retention probability in majority of spices during post-NHM period owing to the increased production in the competing countries like China, Bangladesh and Turkey. Besides this, volatility in international prices of spices has led to decrease in foreign exchange earnings from spice trade. Steps need to be taken to maintain the same level of foreign exchange earnings as before so that more new importers in the market can be reached and India should develop modern infrastructure to encash this competitive advantage.

KEY WORDS : Direction of trade, Transition probability matrix, Spices, National horticulture mission

How To Cite This PAper : Anantha, Venkata Prasad Babu and Sidana, Baljinder Kaur (2019). Economic analysis of export performance of major Indian spices. Internat. Res. J. Agric. Eco. \& Stat., 10 (2) : 302-310, DOI : 10.15740/HAS/IRJAES/10.2/302-310. Copyright@ 2019: Hind Agri-Horticultural Society. 